\title{
Animal rights 'terror' law challenged
}

Targeted researchers support the legislation, despite free-speech concerns.

A tough but rarely invoked US law intended to protect researchers from violent and threatening animal-rights activists has stumbled out of the starting gate: last week, a judge dismissed the first prosecution under the law. The decision comes on top of evidence that the legislation has done little to deter illegal incidents, and concerns that it risks restricting free speech.

Yet researchers who have been targeted by activists mostly support the law - and wish that it would be enforced more often and more aggressively. "You could present this as a setback," says John Ngai, a neuroscientist at the University of California, Berkeley, and the university's spokesman on animal research issues. "But this is one step in a lengthy process. The wheels of justice grind really slowly."

The 2008 Animal Enterprise Terrorism Act (AETA), which replaces a less powerful statute, is designed to help end campaigns of harassment against academic scientists. It outlaws property damages at universities and threats that produce a 'reasonable fear' of death or injury for researchers or their relatives.

The law's first major test came in February 2009, when four animal-rights activists - Adriana Stumpo, Nathan Pope, Joseph Buddenberg and Maryam Khajavi - were arrested and later indicted under the AETA, for incidents at the homes of several Berkeley researchers in 2007 and 2008. The group, with other protesters, wore bandanas over their faces and wrote messages such as "Stop the Torture", "Bird Killer" and "Murder for Scientific Lies" on the pavement with blue and purple chalk, according to police reports. The protesters allegedly burst through a researcher's door and one of them hit her husband with an object.

But on 12 July, a federal judge dismissed the indictment for being too vague: prosecutors did not say which of the activists' alleged actions violated the law. However, prosecutors are free to re-indict if they can show how particular actions crossed the line.

By classing animal-activist crimes as 'terrorism', the statute has succeeded in bringing more lawenforcement resources to bear on the issue, especially from the Federal Bureau of Investigation, says Frankie Trull, president of the pro-animalresearch National Association for Biomedical Research (NABR) in Washington DC.

Yet Trull has been disappointed with the results so far. Several dangerous crimes remain unsolved, including the firebombing of a house

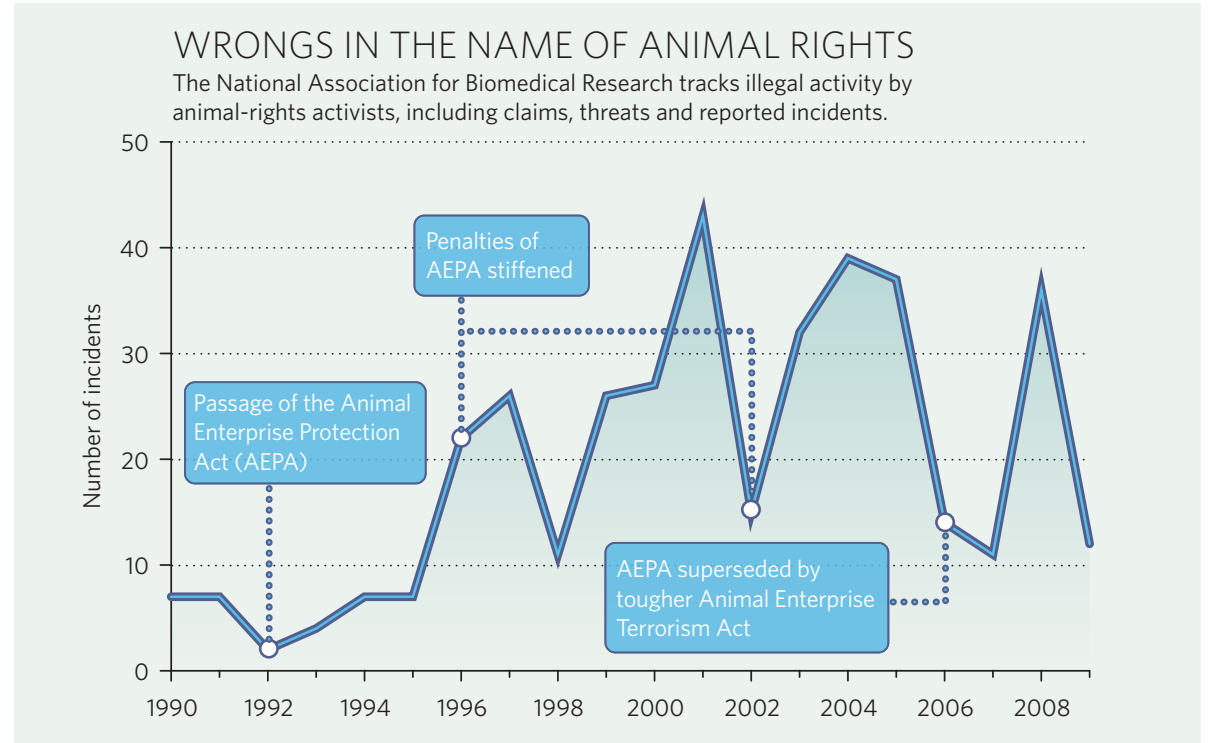

and car belonging to researchers in Santa Cruz, California, in 2008, and the March 2009 torching of a car belonging to David Jentsch, a neuroscientist at the University of California, Los Angeles (UCLA). "Why aren't they arresting these guys?" asks Trull. "It is hard to believe that these extremists are so sophisticated that they don't leave any trail."

There are also few signs that the law has been a deterrent. The number of illegal incidents fluctuates wildly (see 'Wrongs in the name of animal rights'), and analyses by groups on both sides of the issue - the NABR and the activistsympathizing Bite Back magazine - show no clear effect on the number or nature of attacks since the AETA was passed.

Most law-enforcement efforts against animal rights-related crimes in the past decade rely on other legislation. In California, which sees the bulk of US attacks, the state's Researcher Protection Act of 2008 has made

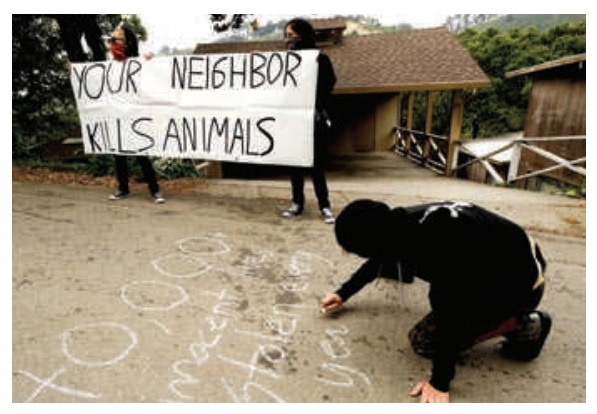

Free speech or terrorism? Activists chalk messages. it a misdemeanour to publish the names and locations of researchers to encourage crimes against them. Under other state laws, UCLA has been granted injunctions that ban several activists from approaching researchers' homes. Activists have also been successfully pursued under anti-stalking laws.

The strong language of the AETA — which in the Berkeley case raises freedom of speech issues, the judge warned - could be making prosecutors wary of using it. Lawyers for the defendants say that much of the activists' activity — chalking, chanting and leafleting should be considered protected 'speech', and therefore be exempt from restriction. According to Michael Macleod-Ball, chief legislative counsel of the New York-based American Civil Liberties Union, "Prosecutors need to be careful about how they use this, because the language in the statute is a little squishy."

Researchers who have been the target of attacks don't want prosecutors to give up yet. Jentsch endured lengthy protests at his home after the burning of his car. He thinks that the AETA could deter protesters who are "actively seeking the boundary of protected speech" to harm researchers without getting arrested. But this won't happen until there are more AETA arrests. "I don't see that the AETA has really affected activists yet," says Jentsch. "It has got to be used to aggressively pursue people who have pushed the bounds of behaviour."

Emma Marris

See Editorial, page 414. 


\title{
Protein mapping gains a human focus
}

\author{
Next phase of the US Protein Structure Initiative enlists biologists to help crack tough human receptors.
}

About one-quarter of approved drugs target members of a single protein family: the $G$ protein-coupled receptors. Members of this clan - the largest protein family in the human genome - control everything from hormone signalling to the perception of light and scent.

Although the receptors are a drug developer's dream, they are a structural biologist's nightmare - difficult to make in the lab and unstable when snatched from their natural home in cell membranes. The human genome encodes more than 800 of these unwieldy proteins, but after decades of work, researchers have determined the three-dimensional structures of only five from humans, leaving many efforts to develop receptor-targeted drugs shooting in the dark.

The latest phase of an ongoing US assault on protein structures - launched last week by the US National Institute of General Medical Sciences in Bethesda, Maryland - aims to improve that record. The Protein Structure Initiative (PSI) has been churning out protein structures since 2000, but its next five-year, US $\$ 290$-million programme will move away from its goal of the past decade, which was to achieve a complete understanding of the elaborate amino-acid folds that comprise a protein and determine its function. Instead, the initiative will pair its 13 protein-structure research centres with a network of biologists in universities and industry in the hope of solving some of the world's most troublesome and medically relevant proteins including the $\mathrm{G}$ protein-coupled receptors.

In the past decade, PSI investigators have been ploughing through a list of human and non-human proteins selected mainly for their diversity. Using techniques including X-ray crystallography and nuclear magnetic resonance spectroscopy, the centres aimed to map the protein 'universe' - a compendium of all the possible ways a protein could fold. Such a map could help researchers to predict a protein's structure from its amino-acid sequence.

\section{Cash concerns}

But the PSI soon faced charges from structural biologists that too much money had been wasted on proteins of little biological interest. Of the roughly 5,000 protein structures solved by the PSI to date, only 128 are human proteins. In 2007, a PSI advisory committee agreed with the criticisms, noting that the PSI's mapping attempts were unlikely to bear fruit: at the time, structure initiatives worldwide had determined the folds for only about $1 \%$ of protein families.

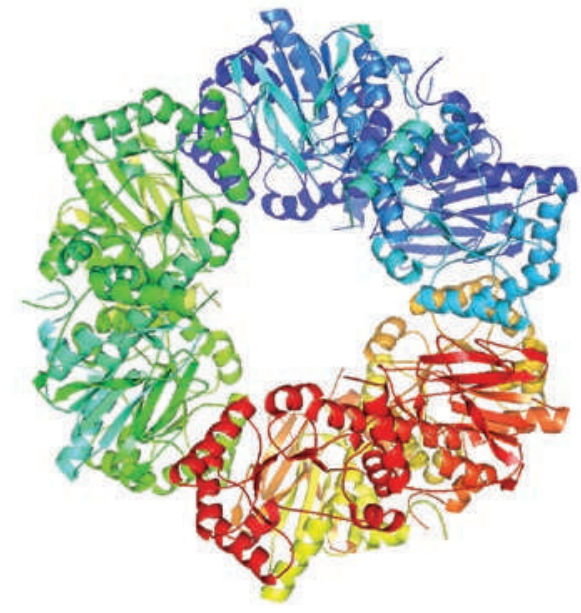

Almost 5,000 protein structures have been solved by a US effort - but only 128 are human proteins.

Even so, that was enough to improve protein modelling, says Johan Weigelt, a structural biologist at the Karolinska Institute in Stockholm. "A lot more structures can be modelled now than could be modelled five years ago, and that's thanks to the PSI," he says. "But for the majority of the biological community, it just wasn't that interesting."

Other projects have tackled protein-structure determination on a grand scale while keeping biology at the centre. The Structural Genomics Consortium, for example, links scientists in the United Kingdom, Canada and Sweden. Funded by a mixture of public and private funds, the consortium specifically targets proteins that are important for human health. Similarly, Japan's Targeted Proteins Research Program, which receives about 4 billion yen (US $\$ 46$ million) a year, focuses on proteins that are crucial in human health, food production and fundamental biology questions.

The PSI will now adopt a similar approach: its next five-year phase has been named PSI:Biology and will fund ten collaborations with biologists. For example, one of the PSI's 13 centres, the Northeast Structural Genomics Consortium, based at Rutgers University in New Jersey, will team up with outside researchers to tackle proteins that are made in mitochondria - the cell's energy factories - as well as proteins that regulate gene expression. Nine of the centres will focus entirely on challenging membrane proteins such as the $G$ proteincoupled receptors. And the programme overall will take on more human proteins, which are typically larger and more difficult to work with than their bacterial counterparts.

The new emphasis comes as budgets for the PSI centres are tightening. With more biologists to support outside the centres, some of the 13 research hubs are receiving a smaller slice of this year's \$58-million PSI budget. The cuts could pose a problem for the oldest centres, whose equipment has now been in use for a decade, says Gaetano Montelione, director of the Northeast Structural Genomics Consortium, where the budget has been cut by about $30 \%$.

Cheryl Arrowsmith, a structural biologist at the University of Toronto in Ontario, Canada, and principal investigator in the Structural Genomics Consortium, wonders whether PSI:Biology will foster enough interaction with biologists. She notes that, unlike the international consortium, the PSI's major research centres will not employ biologists on site, which she says is useful because solving structures often requires detailed knowledge of a protein's unique biochemistry. For example, some proteins are more stable and thus more amenable to crystallography when bound to a natural partner they might normally encounter in a cell.

Meanwhile, one member of the PSI advisory committee, structural biologist Michael Levitt of Stanford University in California, has recanted his criticism that the programme's earlier focus on folds was quixotic. After the committee met, Levitt performed his own calculations of how large the protein universe is. He found that seemingly unique folds are often merely intricate combinations of previously known folds (M. Levitt Proc. Natl Acad. Sci. USA 106, $11079-11084 ; 2009)$. He now says that worldwide programmes have mapped about $6 \%$ of the protein universe, not 1\%. "And that's actually quite impressive."

Heidi Ledford

\section{Corrections}

The News story 'Animal rights "terror" law challenged' (Nature 466, 424; 2010) incorrectly implied that the targets of harassment by animal-rights activists were all researchers at the University of California, Berkeley. Researchers at the University of California, Santa Cruz, were also targeted.

The News Feature 'Ready for boarding - finally' (Nature 466, 428-431; 2010) wrongly stated that spectroscopy performed by an airborne astronomical observatory doesn't require objects to be as bright as for imaging. In fact, spectroscopy requires more light than does imaging. 